\title{
3
}

\section{Economic Theories and Sustainable Development}

Theories have been applied to understand and forecast economic development. Some leading economists and theorists have set the frameworks for the way we run business today-models that in many ways fail as our society are not sustainable in the long run.

In this chapter, I will provide a brief reflection on some of the key economic theories, its "founders", and how this related to a corporate responsibility for sustainable development. How economics, international trade, organizations, tax, values, banks, governments, and so on work today can all be associated with one or more of the famous economic theorists introduced in this chapter. There were also other schools of thoughts which contributed theories that were skeptical to a free market economy and its focus on economic growth, rather more concerned about other limited resources, overconsumption, and the negative consequences of economic growth. The latter theories have, to a lesser degree, been adopted-maybe because they were not as "comfortable" allowing less of an increase in growth and consumption.

I will start with introducing the key economists that hold more of a skeptical view, continue on with a brief but more thorough overview of the theories of two of the most "applied" views on the framework of 
economic development. In the second part of the chapter, I will introduce economists, who reflected on the societal responsibility of individuals in a business setting, especially leaders. The third part of this chapter will discuss key economists and philosophers who explicitly take into account sustainability and corporate responsibility in their assessment of society and business. The mounting evidence of environmental and social challenges prompted the incorporation of these issues by economists during their time-along the same time of the publication of the Brundtland Report and the launch of the "sustainable development" concept.

In this chapter, I have selected examples of approaches to economic development and corporate responsibilities. It is necessary to be aware of the history and foundation of economic development in our society (where we come from) to understand how to move on in a more sustainable direction (where we want to go). Still, given limited space, as well as the purpose of the book, this chapter only provides a brief overview and many well-known economists are left out.

\subsection{Economists Skeptical to the Societal Pursuit of Economic Growth}

Thomas Malthus, a British economist born in 1766, is well-known for his book An Essay on the Principle of Population. His view, the Malthusian Law, is that population growth is exponential and will always go beyond what is sustainable for the population. Therefore, there will always be people who are hungry and poor. As soon as food becomes available, birthrates increase and consumption grows beyond what is considered to be enough to feed all. Malthus' thoughts are in line with the English economist W. Stanley Jevons born in 1835, who suggested that the more we get, the more we use. The Jevons Paradox claims that increases in resources availability generate increases in resource consumption. For example, an increase in access to energy, similarly with an increase in energy efficiency, will not lead to surplus energy, rather the extra energy available will be immediately demanded and consumed. Both these theories posit that humans naturally push the limits whenever it comes to 
consumption, something we definitely see is happening today. Jevons also suggested the concept of marginal utility of consumption which will be addressed in the final chapter "On ways forward".

Thorstein Veblen, an American economist born in 1857, also observed what we are witnessing in today's society- “conspicuous consumption". He pinpointed that the leisure class (rich people who are not working) were overconsuming - something which is even more challenging today with a rapidly growing middle class and an unsustainable way of living.

Arthur C. Pigou was an English economist born in 1877 engaged in welfare economics. In his book The Economies of Welfare, he introduced the concept of externalities and that such costs should be corrected by imposing a tax, the Pigovian tax. There are some products today that partly account for external costs via a tax, such as a $\mathrm{CO}_{2}$ fee- - but, based on the unsustainable volume of $\mathrm{CO}_{2}$ emissions today, the tax is definitely not high enough.

Common for the above economists is that they warned about several of the problems we are facing today: unsustainable population growth, unsustainable consumption, and that there are external costs associated with using natural resources. However, their views have only to a small degree been taken into account in the economic and social development in the centuries to follow. Why is that so? One hypothesis could be that their suggestions were not "comfortable". Reducing consumption and increasing taxes were equally unpopular at that time as it is today.

\subsection{Examples of Key Economists Anchored in Economic Growth}

Adam Smith, John M. Keynes, and Milton Friedman are three economists whose views are perceived by many over time as laying the foundation of today's society.

Common for the individuals formulating theories and solutions for world development is that they lived in different times. This is especially relevant when it comes to sustainability issues and the current situation. As discussed in Chap. 2, it was not until 1987 that a global agreement 
emerged that we are facing an unsustainable future, especially with regard to environmental challenges and resource depletion. When the first economic theorists lived, resource depletion was not a real issue. Many people were poor and did not have access to land, however, on a broader scale, the land and resources were there. It was only that individuals did not have access to them. If forests were cut down for heating, people could move to a new forest and cut that down. Two hundred years ago, the world population was just over one billion and $\mathrm{CO}_{2}$ emissions were not an issue.

The Industrial Revolution took place at the turn of the eighteenth century. Its defining impact on the economy is associated with the move from handmade production to mass production of goods in factories. The invention of steam engines and access to less expensive iron production technologies, only served to speed up the industrialization process. Rural to urban migration to work in factories combined with the growth of international trade formed the basis for the non-sustainable society that we have today.

Describing these three economist views, I will start by reviewing the theories based in their time of departure, and secondly, I will discuss how this relates to corporate responsibility and sustainable development today.

\section{Adam Smith (1723-1790), The Father of Economic Theory}

Adam Smith was a Scottish philosopher and moralist born in 1723 . He lived parallel to other renowned philosophers such as David Hume, who was actually a good friend to Smith. In his book The Theory of Moral Sentiments published in 1759/1976, his focus was based on moral and social behavior of individuals. He recognizes that self-interest forms the basis of human nature and people's behavior. At the same time, he argues that people are not only egoistic, but also care about others. This prudence and justice for people for a societal care is partly based on what is good in a longer term perspective. Smith also claims that we as humans are endowed with natural sympathy toward others. If we see someone in pain, we experience empathy and want to help. Doing so also renders 
good feelings. In that sense, morality is part of human nature. Smith's views of morals and the good way of living have parallels to Aristotle's views.

Today, Smith is more known as an economist. The fact that Smith's views on economics are anchored in a more philosophical line of thought is often ignored. However, his views on human nature are relevant for his thoughts on people in a business setting. At his time, economics was not a field of research, and, as one of the first thinkers focusing on economics, Smith is later known as the "father of economic theory". His book $A n$ Inquiry into the Nature and Causes of the Wealth of Nations (The Wealth of Nations) was published in 1776/2008. His concept of economics as articulated in his book almost 300 years ago still prevails today.

Maybe the fact that Smith lived in the early stages of industrialization impacted the relevance and interest in human behavior and morals associated with economics and business. Given that prior to the age of industrialization, most people were farmers or manufacturing simple products mostly by hand, there was an implicit potential for a better life through access to products if production became more efficient. He thus argued for the advantages of "mass production". Even though this would lead to some people, the owners of the capital, getting rich, he also argued that the increase of products would increase the living standards of the majority of the population, the poor people. Suddenly everyone could afford not only one shirt but two.

In his opinion, the government should not intervene with taxes and laws to retain money for the rich. The rich owners of the capital would have empathy with the workers and people in general and share their wealth out of good morals, not because they would have to. Social recognition and respect would be their motivation and gain for such an approach. That the market will correct itself, without intervention of governments, is known by the metaphor "The Invisible Hand". His view was that this type of market liberalism, an unregulated market with unlimited growth, would lead individual interests to fulfil a common goal.

It can be perceived as Smith's view on the morality of individuals was based on a sense by fairness, social concern and care as expressed in Chapter II of his 1759 book The Theory of Moral Sentiments: "He is certainly not a good citizen who does not wish to promote, by every means in his power, the welfare of the whole society of his fellow-citizens". Here 
he claims that the societal responsibility should be anchored in individuals and not in governmental actions. However, relative to the fact that today, for example, the richest one percent of Americans own 40 percent of the country's value, very few act on their societal responsibility along the lines of, for example, Bill Gates (Ingraham, 2017). It might seem like Smith did not expect people to be as greedy as they/we actually are.

\section{Adam Smith and Sustainable Development}

During Smith's time, there were no resource limitations, no international mass production and the population was only a fraction of what it is today. Global warming and threats to biodiversity were both non-issues. Today, people still discuss whether the concept of an "Invisible Hand" actually works, but most of us will agree that the premises of Smith's theory, the opportunity of unlimited growth along the same lines as today, is definitely not the case.

His belief that the rich will eventually think beyond their own selfinterest and share and do good with their money has to some extent been supported. However, even though Rockefeller, Alfred Nobel, and Bill Gates give back to the poor and support collective goods, these examples are more exceptions than an overall trend (Hodak, 2007).

It is evident that Smith's model, at least the way it is interpreted, misses important elements and facts of our times. Today's unsustainable situation is a proof that the "Invisible Hand" has not guided our development in the direction of sustainability. Smith's model needs to be revisited and extended to be applied to the pursuit of sustainability.

\section{John M Keynes (1883-1946), Macroeconomics}

John M Keynes was British and born in 1883. He is known as the founder of macroeconomics through his book General Theory of Employment, Interest and Money, published in 1936/2018. The situation society was facing at that time was poverty, unemployment, and depression after the First World War. His argument was that the government had to step in to 
get society "up and going". With poverty, people did not have money to purchase, and when there were no customers and demand, there was no point in production. According to his theory, the government should go in and create demand with focus on common goods, like construction, roads, rails, and provide loans with low interest. That would generate jobs and eventually demand for other more consumer-oriented goods.

In Keynes' view, the government had a central role to manage and balance the economic development and "steer" with regulations and taxesthat is, seemingly opposite Adam Smith.

Keynes theory was later applied in the Bretton Woods agreement in 1944 at the end of the Second World War. He played a central role in these negotiations for international finance collaboration. His view on regulations nation wise extended to a global level. International interventions and regulations would in his view form a basis for a development that was good for all. Keynes had a key role in the establishment of both the World Bank and the International Monetary Fund in line with his belief in the importance of global collaboration. Neoclassical synthesis combines Keynesian- and neoclassical theories. The economy must be founded on fiscal and monetary policies, but in the long term humans' main focus is on maximizing marginal utility, that is, want the most for the least.

\section{John M Keynes and Sustainable Development}

Today the level of government regulations are much more encompassing than when Keynes lived, that is, more in line with Keynes views. At the same time, we also see that with the non-sustainable development we have experienced in the last few decades, government interventions, at least how these have been conducted so far, have not been successful. His argument for international collaboration and steering is however more important than ever. Whereas Keynes argued for global collaboration on a monetary level, additional collaboration on environmental and social issues are crucial to solve global challenges. Furthermore, the neoclassical economic concept, arguing that humans primarily seek to maximize economic utility, is challenged. Today, the social and environmental 
challenges are very visible. For those who have their primary survival needs met, social and environmental issues are becoming increasingly more important. It could therefore be argued that these variables also should be included in the neoclassical model. Or, alternatively, that the neoclassical model, which overlooks or undervalues ecological concern and value, should be rejected as an obstacle to achieve sustainable development.

Still, his vision, presented in the chapter "Economic Possibilities for Our Grandchildren” in the book Essays in Persuasion in 1930 (Keynes, $1930 / 2010$ ), predicted that a hundred years onward, the standard of living would be at a level where nobody needed to worry about work or making money (Kolbert, 2014). Assuming "no important wars and no important increase in population, the economic problem may be solved". Now, 90 years later, we can confirm that this vision is not fulfilled. Keynes was however right on his prediction of several issues, even though he underestimated the greed of humans. Just as with Adam Smith's, important variables related to environmental challenges and negative consequences of industry are missing in Keynes model. Also, both thought that at a certain level of consumption, when the needs are met, people would be content, help others, and not pursue greed and continuous growth in irresponsible consumption. Unfortunately, people are not as virtuous as they expected us to be.

\section{Milton Friedman (1912-2006), Social Responsibility of Business Is to Increase Its Profits}

Milton Friedman is a well-known American economist and a great supporter of the market economy. In that sense, his view is more in line with Adam Smith's belief. In 1976, he received the Nobel Prize in Economics for various contributions to economic analysis. Sustainability and corporate responsibility were not explicitly part of this field of research. However, based on his views on the purpose of corporations and their goals and responsibilities, he has become a cornerstone for corporate responsibility claims. 
Friedman's opinion, expressed in a famous and extensively referenced article in the New York Times in 1970, "The Social Responsibility of Business is to Increase its Profits" (Friedman, 1970), is claimed to be out of date and also wrong. This statement is primarily used to support arguments against corporate social responsibility and that business has a responsibility beyond making money. However, I would argue that selective arguments are taken out of context and actually, the article argues that corporations have a social responsibility.

\section{Milton Friedman and Sustainable Development}

Like many of the well-known economic theorists, their name often functions as a cue for economic school of thoughts. When referring to Adam Smith, people think of the free market and when mentioning John M Keynes, people think about the need for government regulations. When mentioning Friedman in the context of corporate responsibility and sustainability, people might think his contributions to economics are against such responsibilities. Holding this opinion, it would suggest the person never read the full article in the New York Times that they are referring to.

The article, with the provocative title "The Social Responsibility of Business Is to Increase its Profits", actually, in my view, supports the argument that companies have a social responsibility—as long as it is associated with profit. The following are two excerpts from the article that I think support the argument of a responsible company. However, the key is not just to think philanthropy when profits are available, but rather make responsibility part of the core business. How to do this in practice will be addressed later in the book.

The corporate executive should act as an agent for the company, not a principal, and not spend "the money of his employers or the time or energy he has contracted to devote to their purposes." There is a culture in several countries, and especially in the United States, where philanthropy is common. Many companies donate up to several percentage of its net profit to good causes. By donating to causes that involve, for example, employees' engagement can lead to improvements in employees' corporate affection and commitment. This again can contribute to better 
work performance and profit. However, if the donations are associated with the CEO's personal interest, which often is the case, this is not an action responsibility that is good for the company in general and its profit.

The corporate executive should "make as much money as possible while conforming to the basic rules of the society, both those embodied in law and those embodied in ethical custom." Most people agree that corporations should follow existing laws and regulations-even though this is not always the case. Friedman made the point that this is a contribution, as following laws is more important than philanthropy. In this quote, Friedman also mentions "ethical custom".

Today, pursuing sustainability is actually becoming an "ethical custom". Later in the book, there are examples of many companies, which go beyond what they are legally required to do-because it is good business. For example, companies are focusing on energy efficiency and reduction of $\mathrm{CO}_{2}$ emissions. There are limited regulations demanding companies to become more energy efficient. However, investing in more efficient heating technology might be good business as well as good for the environment, thus reducing $\mathrm{CO}_{2}$ emissions. This is what I would call a "responsible business" and it is in line with Friedman's claim to make profit as well.

\subsection{More Views on the Theories of the Responsibility of Individuals and Business Leaders}

Prior to Milton Friedman, there were other economists who had reflected on the responsibility of the businessmen. Maurice Clark and Howard Bowen are two such examples. The latter based his explicit reflection of the responsibility of the leaders of corporations that goes beyond generating profit. 


\section{J. Maurice Clark (1884-1963), From Individualism to Social Mindedness}

John Maurice Clark was a leading American economist. His focus was on institutional economics and responsibilities of different stakeholders, such as individuals and corporations. His reflections on corporate responsibilities are especially relevant with regards to sustainable development. In 1916, he wrote the article "Changing Basis of Economic Responsibility" which addresses the responsibilities of companies and men. At that time, more than 100 years ago, narrow individualism was the standard, and Clark argued for the necessity of moving toward a sense of "solidarity and social-mindedness". This also implied a more encompassing responsibility for doing business: "We have inherited an economics of irresponsibility. We are in an economy of control with which our intellectual inheritance fits but awkwardly. To make control really tolerable we need something more; something which is still in its infancy. We need an economics of responsibility, developed and embodied in our working business ethics" (Clark, 1916, p. 210).

\section{J. Maurice Clark and Sustainable Development}

Clark's article on the responsible businessman was one of the first to explicitly address that businessmen have a social responsibility beyond just making money. At that time, the key stakeholder was employees, and, again, the environmental degradation and its international consequences were not issues. His argument that employees should not be treated like "industrial machines", using "charity" to repair the damage originated in poor working conditions. Whereas rights and recognitions are established in the developed world, working conditions in developing countries are in many cases in line with what Clark described. Today, what Clark suggested in 1916 with regards to social responsibility is widely expected of corporations, even though the responsibility is not always fulfilled. 


\section{Howard Bowen (1908-1989), Social Responsibilities of the Businessman}

Howard Bowen was an American economist. From a sustainability and corporate responsibility point of view his book Social Responsibilities of the Businessman published in 1953 was an important contribution to awareness and focus on corporate responsibility (Bowen, 1953). Bowen's understanding of the social responsibility of businessmen was "the obligation of businessmen to pursue those policies, to make those decisions, or to follow those lines of action that are desirable in terms of the objectives and the values of our society". He argued, somewhat in line with Adam Smith, that companies should take responsibility, and not depend upon governmental regulations (which was more in line with Keynes). He argued for establishing a code of practice for corporations to avoid exploiting stakeholders, including customers and labor.

\section{Howard Bowen and Sustainable Development}

Bowen's main contribution was at an early stage to put forward and remind about the concept of "responsible businessmen" explicitly as a title of a book. That increased awareness and discussion. It can be argued to which extent his vision was achievable. Is it actually realistic that companies' voluntary would follow a code to reduce competitive struggle and become "well mannered" and let go of business without going out of business? If so, that would be more in line with Aristotle's concept of virtue. Social responsibility today is maybe more based on duty ethics, it is something that is expected and or utilitarianism, that behaving responsible can lead to better profit. 


\subsection{Economic Growth, Gross Domestic Product (GDP), and Sustainable Development}

Economic growth is the increase in the production of goods and service over a specific period. For a country, this is usually measured as Gross Domestic Product (GDP). The pursuit of GDP growth as a "success indicator" might be a challenge with regard to sustainability. GDP was "invented" by Simon Kuznets, associate director of the Bureau of Planning and Statistics at the War Production Board and Nobel Prize laureate, in the 1930s as a means to measure a country's economic development (Wharton Magazine, 2007).

The GDP does not take into account environmental damages such as the consequences of $\mathrm{CO}_{2}$ emissions, reduced biodiversity, and environmental accidents. On the contrary, an environmental disaster, like for example a major oil spill, will have a positive impact on GDP and render growth. The reason is that cleaning up such a spill increases the need for product and services which then add to the GDP. Continuous overfishing for example is good for the GDP — until the day there are no fish left. A sharing economy, where people do not purchase new products, but share with others, does not contribute to GDP. In addition, the fact that GDP does not measure well-being, happiness, level of equality, and so on is a key problem using GDP as an approach to measuring growth. Kuznets himself warned that the GDP was not developed to measure societal development.

\subsection{Business Theory for Corporate Responsibility and Sustainability}

So far in this chapter, I have described key economic theories which form the foundation of our current economic system, as well as examples of economists who during the last two centuries have been skeptical to the economic models of our society. The majority of these thoughts were developed before society developed a common awareness and agreement 


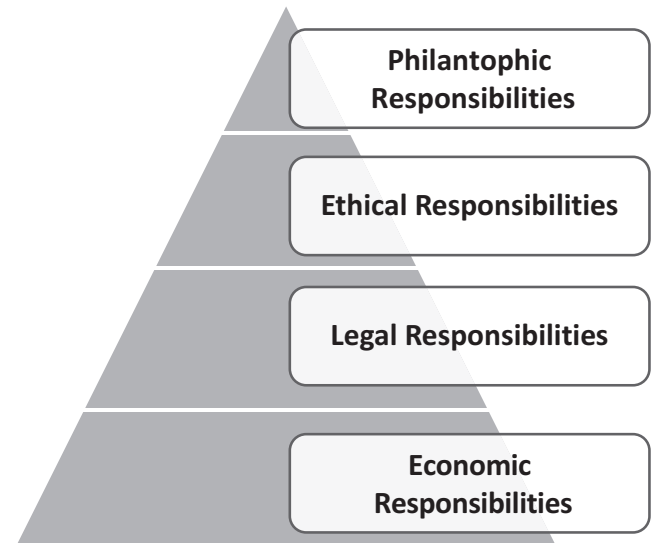

Fig. 3.1 Carroll CSR Pyramid

on the global environmental challenges we confront together. In the next section, I will put forward key theories on business models including the challenges and opportunities associated with sustainability and corporate responsibility.

\section{The CSR Pyramid}

Corporate responsibility is closely related to prioritizing. As addressed above, a key element in this discussion is the question for what the corporation is actually responsible. Archie B. Carroll, an American professor, developed the Pyramid of Corporate Social Responsibility (CSR), which illustrates a suggested priority list (Carroll, 1991). The model is presented in Fig. 3.1.

According to the model, corporate managers' key responsibility is to make money and then to fulfil legal requirements. Thereafter the company's responsibility is to behave ethically right. Finally, if there is any extra money available, the company should engage in philanthropic engagement and donations. Whether or not the priority for corporate operations is to make money and that operating according to law is second in priority have been discussed. 
The approach to business responsibility reflected in this model is anchored in American corporate cultures. It suggests that philanthropic contributions, doing good for society, are something to be done if there is extra money available. As has already been mentioned, and will be an important element throughout this book, societal responsibility and sustainability have to be integrated in the company-not being an act of doing good when a surplus of money is available.

Furthermore, the order of the different elements in the pyramid varies depending on culture. In Africa for example, studies have found philanthropy is relatively more important and replaces Legal Responsibilities in Carroll's pyramid (Visser, 2005). Emerging markets will be further discussed in Chap. 8.

\section{Stakeholder Theory}

Corporate responsibility is closely related to which group or individuals that corporations should prioritize. Stakeholder theory differs from the CSR Pyramid in that the first model pinpoints different groups, whereas the latter focuses on areas of responsibility.

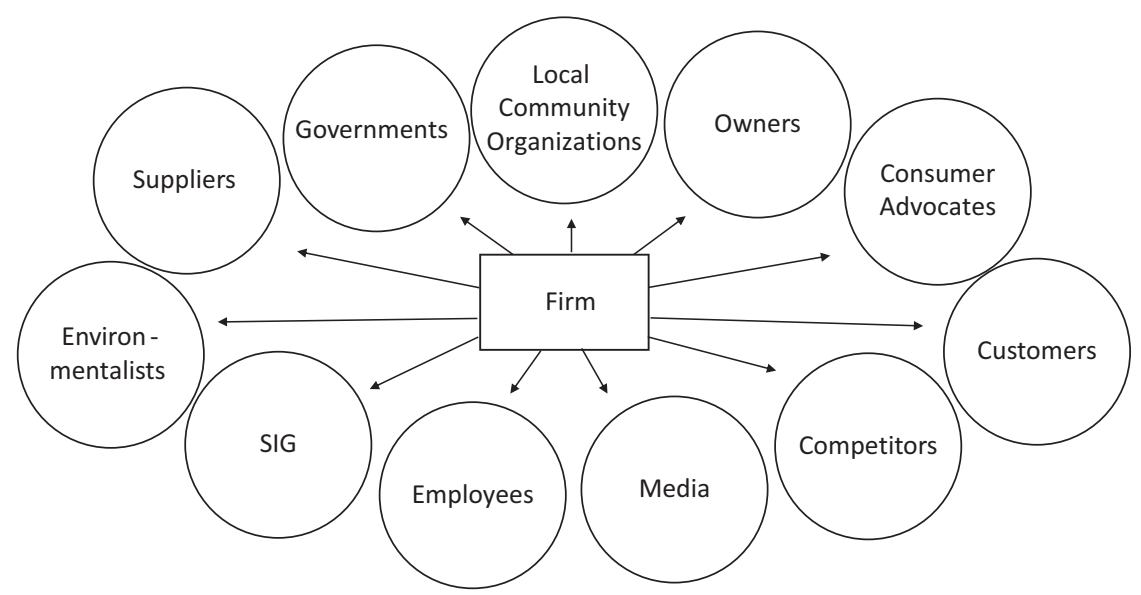

Fig. 3.2 The stakeholder model 
Originally corporations had few stakeholders. In the beginning of the industrialization process, the key stakeholders of the corporation were the owners of the capital. Usually the managers, suppliers, customers, and employees had less power and therefore were less important. This latter group of stakeholders had very few rights, without any labor organizations, the owners decided wage and working conditions without any interference from employees. If competitors emerged, employees left the company for better wages. As industrialization went on, new stakeholders came along. Governments for example started having important impact on how corporations operated as did trade unions.

R. Edward Freeman, an American philosopher and business professor, is often put forward as the founder of stakeholder theory, who first visualized the model in his book Strategic Management, A Stakeholder Approach (Freeman, 1984). Still, many economists had addressed stakeholder theory prior to Freeman. The Swedish management theorist Eric Rhenman for example, suggested the idea already in 1968 (Rhenman, 1968).

Freeman's model is presented in Fig. 3.2 and consists of 11 different stakeholders. The model has been extensively revised over the years to include several more stakeholders that companies have today.

A sustainable company has to take different stakeholders into account and balance priorities. Some customers prioritize sustainable products (climate neutral, guaranteed no child labor, etc.) and other customers prioritize low price, so the company must decide which customer group to target and satisfy. More details on stakeholder management will be included in Chap. 8.

\section{The Triple Bottom Line}

The bottom line is usually referred to as the company's result, being profit or loss, reflecting total income less total expenses. Elkington's, a British author and entrepreneur, introduced The triple bottom line concept which extends corporate performance metrics beyond the financials. The model includes the economic bottom line, the environmental bottom line, and the social bottom line (Elkington, 1998).

Initially, the concept of corporate responsibility was associated with environmental issues, focusing on reducing emissions and more efficient 
use of resources. Societal issues did not receive the same attention. They were usually perceived as political issues and within the domain of the state, such as religious prosecution or racial discrimination. Even though human rights and working conditions for example were important elements of corporate performance, it was not incorporated in the responsibility setting in line with environmental issues. Human tragedies such as Bhopal and sweatshop labor among Nike's suppliers (see Chap. 5) brought attention to the social responsibility of corporations.

In his book Cannibals with Forks, Elkington describes the environmental bottom line as the extent to which the company's "natural capital" can be quantified and accounted for. He calls for more focus on measuring the environmental impact of corporations in terms of new metrics. The social bottom line addresses the importance of companies' social capital, both internally and externally. In the globalization process, issues such as treating workers well, human rights, indigenous people, community relations need attention. Manufacturing products that are safe to use and consume and employee training are also part of the social component of the triple bottom line. The economic bottom line addresses the long-term indicators of sustainability. He pinpoints that company value goes beyond assets minus liabilities and Elkington rebukes traditional accounting for not assessing the long-term sustainability of a company.

The triple bottom line is often referred to as the three "P"s; planet (environment), people (social), and profit (economic). Elkington claims that this interpretation of the model is incorrect. In 2018, he actually "recalls" the concept he coined in 1994, claiming that "business success or failure on sustainability goals cannot be measured only in terms of profit and loss. The wellbeing of billions of people and the health of our planet and the sustainability sector's record in moving the needle on those goals has been decidedly mixed." He clarifies that the "economic" element is not only financial profit, but contains a broader perspective as addressed above (Elkington, 2018).

Still, companies cannot survive if profit is not taken into account. So, what has to change is the manner in which profit is calculated. To do this, we need a different accounting approach where the true societal impact and cost of the different elements of the model are taken into account. This is often referred to as full cost pricing, which will be addressed in Chap. 6 on the circular economy. 

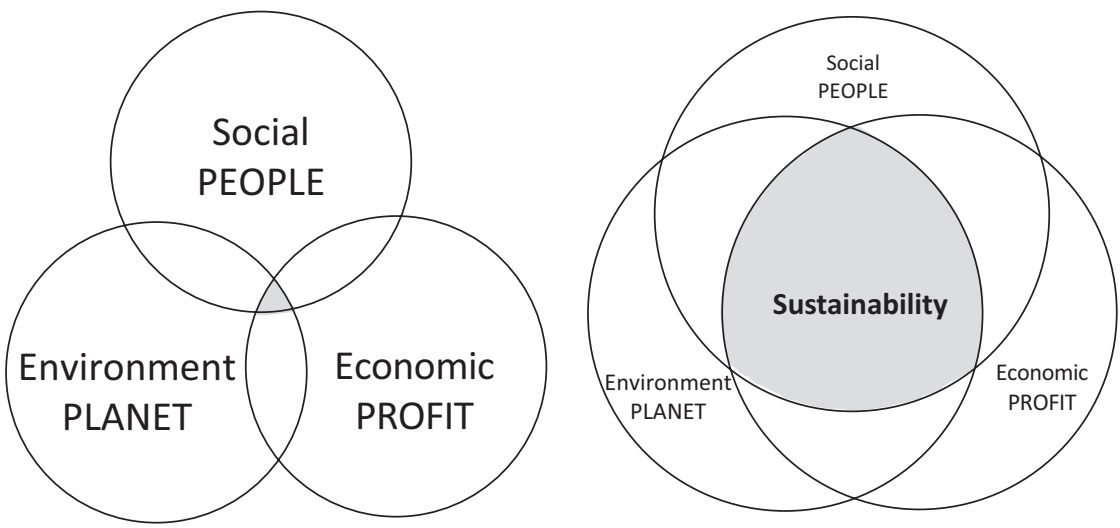

Fig. 3.3 The triple bottom line model-illustrating the move to sustainable development, integrating environmental, economic, and social issues in business operations

Corporations have to find a balance between the economic, environmental, and social bottom lines. The area in the middle, where the different impacts and results of business operations overlap, is where business is "sustainable". This concept is illustrated in Fig. 3.3.

\section{Creating Shared Value}

The concept of "shared value" is about doing good for society and business at the same time. "Shared value creating focuses on identifying and expanding the connections between societal and economic progress" (Porter \& Kramer, 2011). The concept argues that for a long time companies have been perceived as the originators of our unsustainable development through poor working conditions, emissions, and inefficient use of resources. The argument is that companies in general will continue to behave in this unsustainable manner, even when being criticized by for example NGOs for their unsustainable conduct. In this "old model", companies are perceived as the source of the problem.

In the Shared Value Model, companies are identified as the solution for sustainable development, not as the problem. The argument is that in the 
long-term, sustainable behavior can increase profitability for corporations. However, in this setting, it is crucial to focus on the right issues associated with the company's impact.

In the United States, corporate philanthropy is very common. Actually, the median percentage of donations of the 250 world's largest companies was almost one percent of pre-tax net income (McClimon, 2020). Porter and Kramer claim that this is not sustainable. If for example the company is not doing well financially, donations are reduced for that year. Donations are often not an efficient way of improving the community, rather what makes the most impact is when corporations make sustainability part of doing business - and to increase profit. "Societal needs, not just conventional economic needs, define markets, and social harm can create internal costs for firms." Instead of donating money to NGOs and the local community, the company should collaborate with NGOs and integrate community challenges into its operations.

The 2011 ME Porter and MR Kramer's article presents the concept of "Creating Shared Value" (CSV) as the new concept relative to Corporate Social Responsibility (CSR). The article and the concept have received lots of attention and citations. That is one of the reasons I included it in this chapter. Even though the term CSV was new, the concept was not, when the article was published. It can be argued that the article "kicks up open doors". In Europe at least, corporate philanthropy has not been a central element in CSR as it is in the United States. The importance of collaboration with different stakeholders as part of business was already a key point in both stakeholder theory in 1984 and the triple bottom line concept in 1994.

\subsection{Trends and Theories Capturing the Sustainability Issues in Business Models}

Most of the economic theories our society is built on, as mentioned, do not consider environmental and social issues. The goal, economic growth, has been based on increasing production, consumption, and resource 
use. This has had considerable negative consequences on the environment through for example climate change, pollution, and loss of biodiversity. Economic growth based on overconsumption has also had negative consequences for human health through for example poor health, loneliness, inactivity, obesity, and so on. Since the turn of the century, economic theories acknowledging societies' sustainability challenges have come forward. This again influences business models.

The move from "brown growth", growth based on fossil fuel, to "green growth", growth based on renewable energy, is one example of changes in economic models — the purpose being creating wealth without harming the environment. The Green Economy is a central focus area of the European Commission (EC) . Bioeconomy, extending economic theories to include ecology, environmental => environment, energy, food supply, and natural resources, has also received more attention and is now part of the EU strategy.

Given the complexity of sustainable development, common for the pursuit and integration of new economic models is that different disciplines are included. Concepts such as the Caring Economy (Wenden, 2008) and the Doughnut economic model (Schokkaert, 2019) extend the concept of Green Growth and Bioeconomy to also include social issues as health, peace and justice, education, and so on. "Ecological economy" is an example of the inclusion of ecology in the economic model (Spash, 2013). Other examples of relevant fields to be included are psychology, sociology, philosophy, public policy, and so on. The Doughnut economic model presented among others in Kate Raworth's book Doughnut Economics is an attempt to provide a visualization of a sustainable society. The outer ring of doughnut represents the planetary limits, the inner ring represents the minimum living standards as set by the SDGs, whereas the hole in the middle, represents the proportion of people lacking access to basic essentials. To reach the goal that everybody should live in the edible part of the doughnut requires a substantial redistribution of consumption, away from today's situation where the richest one percent owns half of the world's wealth. Raworth is critical of many new growth concepts, including green growth, and in general challenges the focus on growth. Rather, she pinpoints a level of maturity at which the goal is that people are thriving. 
Some of the elements in these new theories of growth and inclusion of different disciplines can be recognized in theories brought forward by scientists centuries and decades before the "world consensus" on sustainability global challenges that emerged in the 1970s. Aristotle, who is frequently referred to today with regard to (un)sustainable behavior, was involved in physics, zoology, psychology, economics, biology, and so on. Thomas Malthus who warned about unsustainable growth, was originally a priest, and Thorstein Veblen who warned about overconsumption, was a sociologist. Today, in line with what was the case when these scientists lived, the challenge is how to actually integrate these challenges and models in our growth concept.

Since the 1970s, when politicians, corporations, researchers, and people in general began explicitly recognizing society's sustainability challenges, revised and new business models including social and environmental elements have emerged. It is only a few decades ago that waste was dumped legally in the water, polluted emissions from factory pipes were not treated, and people were driving around in gas guzzlers. Realizing the cost of cleaning up such unsustainable ways of doing business has led to increases in resource prices and legislation to reduce the negative impacts. In Chap. 6 Circular Economy, I will look at a business model recognizing the sustainability challenges we are facing today.

Moving from "weak sustainability", substitution of natural capital with other types of capital, to "strong sustainability", not damaging natural resources, is also a growing field of research (Hankammer et al., 2021). Degrowth and downsizing economic throughput are examples of more expansive and challenging economic models. Even though full decoupling of economic growth and resource consumption might not be possible, we can come a long way by giving natural resources an economic value capturing external costs, that is, integrating externalities, along the lines of the Pigouvian tax. Degrowth, as in reduced consumption of natural resources, is good and achievable, but not without governments assigning value and pricing in external costs into resources that are currently used for free. To a large extent, the move from gas guzzling cars to small efficient cars can be credited with increases in gasoline prices. Taxes on cigarettes reduce the 
number of people smoking, resulting in prevention of diseases and also generating funding to treat smoking related health costs.

In Chap. 5 The business case for sustainability, I will look at different business approaches to sustainability and the move from a business model that accommodates sustainability to a business model that explicitly incorporates sustainability.

In Chap. 12, The way forward, I will reflect on what is necessary to transition to a more sustainable track for society.

\section{References}

Bowen, H. R. (1953). Social responsibilities of the businessman. Harper.

Carroll, A. B. (1991). The Pyramid of corporate social responsibility: Toward the moral management of organizational stakeholders. Business Horizons, 34(4), 39-48. http://search.ebscohost.com/login.aspx?direct=true\&db=bth $\& A N=9707074820 \&$ site $=$ ehost-live

Clark, J. M. (1916). The changing basis of economic responsibility. The Journal of Political Economy, 24(3), 209-229. https://doi.org/10.1086/252799

Elkington, J. (1998). Cannibals with Forks: The triple bottom line of 21st century business. John Wiley \& Sons, Ltd.

Elkington, J. (2018). 25 years ago i coined the phrase "Triple Bottom Line." Here's why it's time to rethink it. Harvard Business Review Digital Articles, 2-5.

Freeman, R. E. (1984). Strategic management: A stakeholder approach. Pitman.

Friedman, M. (1970). A Friedman doctrine-The social responsibility of business is to increase its profits. The New York Times. https://www.nytimes. com/1970/09/13/archives/a-friedman-doctrine-the-social-responsibilityof-business-is-to.html

Hankammer, S., Kleer, R., Mühl, L., \& Euler, J. (2021). Principles for organizations striving for sustainable degrowth: Framework development and application to four B Corps. Journal of Cleaner Production, 300, N.PAG-N. PAG. https://doi.org/10.1016/j.jclepro.2021.126818. https://login.ezproxy. library.bi.no/login?qurl=https://search.ebscohost.com/login.aspx?direct=true $\& \mathrm{db}=\mathrm{bth} \& \mathrm{AN}=150008795 \&$ site $=$ ehost-live \&scope $=$ site

Hodak, M. (2007). Adam Smith's Folly. Forbes. https://www.forbes.com/2007/ 10/24/adam-smith-corporations-markets-marketsp07-cx_mh_1025hodak. html?sh=10d5a65e $3 \mathrm{c} 1 \mathrm{~b}$ 
Ingraham, C. (2017, December 6). The richest 1 percent now owns more of the country's wealth than at any time in the past 50 years. The Washington Post. https://www.washingtonpost.com/news/wonk/wp/2017/12/06/ the-richest-1-percent-now-owns-more-of-the-countrys-wealth-than-at-anytime-in-the-past-50-years/

Keynes, J. M. (1930/2010). Economic possibilities for our grandchildren. In Essays in Persuasion (pp. 321-332). Palgrave Macmillan. https://doi. org/10.1007/978-1-349-59072-8_25

Kolbert, E. (2014). No time: How did we get so busy? New Yorker. https://www. newyorker.com/magazine/2014/05/26/no-time

McClimon, T. J. (2020). Corporate giving by the numbers. Forbes. https://www. forbes.com/sites/timothyjmcclimon/2020/01/16/corporate-givingby-the-numbers/?sh=18375d1a6c51

Porter, M. E., \& Kramer, M. R. (2011). Creating shared value: How to reinvent capitalism-and unleash a wave of innovation and growth. Harvard Business Review, 89(1-2), 62.

Rhenman, E. (1968). Industrial democracy and industrial management. Tavistock. Schokkaert, E. (2019, Spring). Review of Kate Raworth's Doughnut economics. Erasmus Journal for Philosophy \& Economics, 12(1), 125-132. https://doi. org/10.23941/ejpe.v12i1.412. https://search.ebscohost.com/login.aspx?dire $\mathrm{ct}=$ true $\& \mathrm{db}=\mathrm{bth} \& \mathrm{AN}=137859877 \&$ site $=$ ehost-live\&scope $=$ site

Spash, C. L. (2013). The shallow or the deep ecological economics movement? Ecological Economics, 93, 351-362. https://doi.org/10.1016/j.ecolecon.2013.05.016. https://login.ezproxy.library.bi.no/login?qurl=https:// search.ebscohost.com/login.aspx?direct=true $\& d b=b t h \& A N=89436681 \&$ sit $\mathrm{e}=$ ehost-live\&scope $=$ site

Visser, W. (2005). Revisiting Carroll's CSR pyramid: An African perspective. In E. R. Pedersen \& M. Huniche (Eds.), Corporate citizenship in developing countries: New partnership perspectives (pp. 29-56). Samfundslitteratur.

Wenden, A. (2008). Discourses on poverty: Emerging perspectives on a caring economy. Third World Quarterly, 29(6), 1051-1067. https://doi. org/10.1080/01436590802201030. https://search.ebscohost.com/login.asp

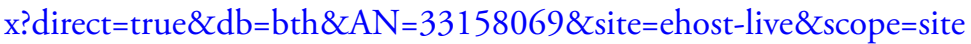

Wharton Magazine. (2007, July 1). Inventor of GNP Measure: Simon Kuznets Hon56 Hon76. https://magazine.wharton.upenn.edu/issues/anniversaryissue/inventor-of-gross-national-product-measure-simon-kuznetshon-56-hon-76-professor/ 
Open Access This chapter is licensed under the terms of the Creative Commons Attribution 4.0 International License (http://creativecommons.org/licenses/ by/4.0/), which permits use, sharing, adaptation, distribution and reproduction in any medium or format, as long as you give appropriate credit to the original author(s) and the source, provide a link to the Creative Commons licence and indicate if changes were made.

The images or other third party material in this chapter are included in the chapter's Creative Commons licence, unless indicated otherwise in a credit line to the material. If material is not included in the chapter's Creative Commons licence and your intended use is not permitted by statutory regulation or exceeds the permitted use, you will need to obtain permission directly from the copyright holder.

(c) (i) 